\title{
Combined stable isotope and gut contents analysis of food webs in plant-dominated, shallow lakes
}

\author{
J. IWAN JONES* AND SUSAN WALDRON ${ }^{+}$ \\ *School of Biological Sciences, Queen Mary and Westfield College, University of London, London, U.K. \\ tLife Sciences Community Stable Isotope Facility, SUERC, Scottish Enterprise Technology Park, East Kilbride, U.K.
}

\section{SUMMARY}

1. To determine feeding links between primary producers, invertebrates and fish, stable isotope analyses and gut content analyses of fish were conducted on the components of four shallow, eutrophic to hypertrophic, plant-dominated lakes.

2. Although separation of basal resources was possible, the diets of both fish and invertebrates were broad, comprising food from different compartments (planktonic, epiphytic/benthic), as well as from different trophic levels.

3. Mixing models were used to determine the extent to which periphyton production supported higher trophic levels. Only one species of invertebrate relied upon periphyton production exclusively.

4. Fish density affected the diets of invertebrates. The response was different for planktonic and epiphytic/benthic invertebrates. The proportion of periphyton production in the diets of zooplankton appeared to increase with fish density, whilst it decreased for other invertebrates.

5. As all zooplankton samples were collected in the open water at dusk, these results are further evidence for the diurnal horizontal migration of zooplankton. Although not conclusive, they are consistent with a behavioural response by invertebrates and zooplankton in the presence of fish.

Keywords: invertebrates, feeding links, fish, periphyton, phytoplankton, zooplankton

\section{Introduction}

Over a range of nutrient concentrations, the communities of shallow lakes can be dominated either by aquatic plants and have clear water, or by phytoplankton and have turbid water (Canfield et al., 1984; Jeppesen et al., 1990). In marked contrast to lakes dominated by phytoplankton, plant-dominated lakes are species rich and complex, both in terms of spatial heterogeneity and biotic interactions (Jeppesen et al., 1998). Whilst in recent years several theoretical and empirical studies have emphasised the importance of trophic interactions for structuring lacustrine communities (Carpenter \& Kitchell, 1993), most research has

Correspondence: J. Iwan Jones, School of Biological Sciences, Queen Mary and Westfield College, University of London, London, E1 4NS, U.K. E-mail: j.i.jones@qmul.ac.uk focused on the pelagic food chain. The information available from shallow, vegetated lakes indicates that their food web structure is far more complex (Diehl \& Kornijów, 1998). Species richness is higher, and primary production from different sources (submerged plants, planktonic and attached algae) is channelled through several routes (Jeppesen et al., 1998). Of these the links between periphyton, grazing invertebrates and fish seem to be of particular importance in determining the structure of the community (Jones, Moss \& Young, 1998; Jones et al., 2002). The growth of submerged plants is heavily influenced by competition from the periphyton growing on their surfaces (Sand-Jensen, 1977). However, it is not nutrients but the abundance of grazing invertebrates that determines the density of periphyton, and hence the expression of this competition (Jones et al., 2002). In turn, predation by fish seems to have a strong

(C) 2003 Blackwell Publishing Ltd 
influence on the abundance of these grazing invertebrates and may be one of the prime determinants of whether shallow lake communities are dominated by plants or by phytoplankton (Brönmark \& Weisner, 1992; Brönmark, 1994; Jones \& Sayer, in press).

In spite of this potentially important role in the functioning of shallow lake ecosystems, our knowledge of the interactions involving plant-associated invertebrates is limited. In direct contrast to studies of phytoplankton-based food webs, very few investigations involving periphyton have spanned more than two trophic levels (e.g. Moss, 1976; Mazumder et al., 1989), and most of these have concentrated on snails (Brönmark \& Weisner, 1992; Brönmark, 1994). What little work there is, suggests that plant-associated grazing invertebrates represent the primary control on periphyton standing crop (Cattaneo \& Kalff, 1986; Kairesalo et al., 1987; Jones et al., 2002) and that the effect of these invertebrates is related more to their overall abundance than to their taxonomic composition (Jones et al., 1998). Many of these invertebrates, although nominally described as grazers, are plastic in their feeding habits (Fryer, 1968), and we do not know the extent to which they depend upon periphyton as a food source.

Stable isotope analysis (SIA) is an important technique for characterising food web structure and following the pathways of energy flow through food webs (e.g. Fry, 1988; Yoshioka, Wada \& Hayashi, 1994; Yoshii, 1999; Grey, Jones \& Sleep, 2001). It is used here to describe the links between the organisms inhabiting four eutrophic to hyper-eutrophic, plant-dominated shallow lakes. Our aim was to determine which invertebrate species were feeding upon periphyton, and subsequently the feeding links between these invertebrates and fish. We also wanted to determine if changing environmental conditions, particularly the availability of phosphorus, influenced these relationships.

\section{Methods}

\section{Site description}

The four lakes used for this analysis are located in Norfolk, U.K., a low-lying, predominantly arable agricultural region in eastern England. The lakes are small (1.7-8.3 ha) and were created by damming sluggish, high-order streams in the nineteenth century or earlier, to rear fish, to provide wildfowl shooting or for aesthetic value. Catchments are small (152$73500 \mathrm{ha}$ ), and either fed by groundwater or by overland drainage (Table 1). Only Bayfield Hall Lake has any significant point source of nutrients upstream. Bluestone Plantation Lake has no visible inflows, and is fed entirely from groundwater. All the lakes are shallow (maximum depth $<2.5 \mathrm{~m}$ ) with submerged aquatic plants covering the majority of the lake area $(>70 \%)$ and communities characteristic of a plant dominated state (Scheffer, 1998). The lakes are alkaline (148-244 meq L ${ }^{-1}$ ) and productive (annual mean chlorophyll a $7-44 \mu \mathrm{g} \mathrm{L}^{-1}$ ). Annual mean total

Table 1 Environmental characteristics recorded for the four study lakes. Water chemistry variables are annual means based on 12 monthly samples collected May 1999-May 2000 with ranges given in brackets where appropriate

\begin{tabular}{|c|c|c|c|c|}
\hline & $\begin{array}{l}\text { Bayfield } \\
\text { Hall Lake }\end{array}$ & $\begin{array}{l}\text { Bluestone } \\
\text { Plantation Lake }\end{array}$ & $\begin{array}{l}\text { Gunthorpe } \\
\text { Hall Lake }\end{array}$ & $\begin{array}{l}\text { Stradsett } \\
\text { Hall Lake }\end{array}$ \\
\hline & $1^{\circ} 3^{\prime} 55^{\circ} 0^{\prime}$ & $1^{\circ} 9^{\prime} 52^{\circ} 47^{\prime}$ & $0^{\circ} 59^{\prime} 52^{\circ} 53^{\prime}$ & $0^{\circ} 28^{\prime} 52^{\circ} 37^{\prime}$ \\
\hline Water sources & River Glaven & Springs & Springs/ stream & Stream \\
\hline Area (ha) & 2.7 & 3.6 & 1.7 & 8.3 \\
\hline Catchment (ha) & 73500 & 367 & 152 & 5023 \\
\hline Maximum depth (m) & 1.32 & 1.64 & 2.45 & 1.84 \\
\hline Alkalinity (meq $\mathrm{L}^{-1}$ ) & $244(203-352)$ & $160(118-200)$ & $210(164-290)$ & $148(41-243)$ \\
\hline $\mathrm{pH}$ & $8.1(7.8-8.4)$ & $7.9(7.5-8.5)$ & $7.8(7.3-8.4)$ & $7.9(7.1-9.7)$ \\
\hline $\mathrm{TP}\left(\mu \mathrm{gP} \mathrm{L}{ }^{-1}\right)$ & $241(328-172)$ & $41(20-59)$ & $65(25-195)$ & $166(28-678)$ \\
\hline $\mathrm{NO}_{3}^{-}\left(\mathrm{mgN} \mathrm{L}^{-1}\right)$ & $2.4(0.8-3.5)$ & $0.7(0.01-2.42)$ & $0.7(0.01-1.6)$ & $1.1(0.0-4.1)$ \\
\hline Chlorophyll $a\left(\mu \mathrm{g} \mathrm{L}^{-1}\right)$ & $7.1(0.4-28)$ & $12.7(2.6-32)$ & $44.1(2.0-370)$ & $12.5(0.4-59)$ \\
\hline Secchi depth (cm) & $103(85-110)$ & $141(80-165)$ & $163(63-247)$ & $142(44-185)$ \\
\hline Macrophyte cover $(\%)$ & 50 & 90 & 90 & 95 \\
\hline Fish $\left(\mathrm{g} \mathrm{m}^{-2} \pm \mathrm{SE}\right)$ & $1.95(0.23)$ & $5.28(0.66)$ & $9.31(1.29)$ & $2.50(0.47)$ \\
\hline
\end{tabular}


phosphorus concentrations indicated that the lakes are eutrophic to hyper-eutrophic $\left(41-241 \mu \mathrm{g} \mathrm{L}^{-1}\right)$. As the inflows are small and turnover times long, organic inputs from the catchment are small compared with organic production within the lakes. The lakes are situated in an open landscape of short grassland used for rearing sheep, except for Bluestone Plantation Lake, which is surrounded by Alder carr [Alnus glutinosa (L.) Gaertner].

Several species of submerged and floating-leaved plants are present in the lakes, mainly Potamogeton spp., Ceratophyllum demersum L., Nuphar lutea (L.) Smith and Hippuris vulgaris L., together with the macroalgae, Cladophora glomerata (L.) Kuetz., Enteromorpha intestinalis Link. and Palmella mucosa Kuetz. All the lakes contain a fish community typical of eutrophic vegetated lakes (Table 2), though the abundance of fish varied among them. The lakes used in this analysis were selected to represent a range of nutrient availability from a larger set being used to study the influence of grazing invertebrates on periphyton abundance (Jones \& Sayer, in press).

\section{Sample collection}

The lakes were visited between 24 June and 8 July 1999. Dominant taxa, representing all trophic levels and potential carbon sources, were collected from each of the lakes. Invertebrate samples for stable isotope analysis were collected by sweeping either plants or benthos with a pond net (mesh size, $330 \mu \mathrm{m}$ ) and sorted live on the bank into different taxa. These invertebrates were then stored live in filtered lake water as separate individual taxa. The water in the containers was changed repeatedly over the next $24 \mathrm{~h}$, whilst the animals emptied their guts. The samples were then frozen. Zooplankton was collected by repeatedly trawling the open water at dusk with a zooplankton net (mesh size, $330 \mu \mathrm{m}$ ) and handled in the same way as other invertebrates.

Seston (predominantly phytoplankton) was sampled on site by filtering lake water onto Whatman GF/C $(1.2 \mu \mathrm{m})$ glass fibre filters that were immediately frozen in a portable freezer. Periphyton was sampled by vigorously shaking a sample of the submerged parts of the plants found in the lake in algal free water, sufficient to remove most attached algae (Jones et al., 1999). The resultant suspension was then passed through Whatman GF/C glass fibre filters in the same way as seston. Periphyton and seston samples were checked with a microscope for any contamination by pieces of plant or animal material, and any found on the filters were removed with forceps. The plants used for periphyton samples, having had the algae removed from their surfaces, were put in bags and immediately frozen. All equipment was rinsed with algal free water between each sample. Samples were taken at five random stations around each lake chosen to represent the dominant plant species present.

To estimate fish abundance, a stop-net (mesh size, $6.5 \mathrm{~mm}$ ) was deployed by hand from a boat, rapidly isolating an area of approximately $35 \mathrm{~m}^{2}$, and the fish

Table 2 Occurrence of fish species and size classes in the four study lakes

\begin{tabular}{|c|c|c|c|c|c|c|}
\hline & & Size $(\mathrm{mm})$ & Bayfield & Bluestone & Gunthorpe & Stradsett \\
\hline Bream 1 & Abramis brama $(\mathrm{L})$ & $<30$ & & & & * \\
\hline Bream 2 & & $50-90$ & & & & * \\
\hline Eel & Anguilla anguilla (L) & $300-600$ & * & & & \\
\hline Perch 1 & Perca fluviatilis $\mathrm{L}$ & $<30$ & * & & * & \\
\hline Perch 2 & & $100-150$ & * & & & \\
\hline Pike 1 & Esox lucius L & $<100$ & & & * & * \\
\hline Pike 2 & & $200-400$ & * & & * & * \\
\hline Pike 3 & & $>500$ & & & * & \\
\hline Roach 1 & Rutilus rutilus (L) & $<15$ & & & * & \\
\hline Roach 2 & & $50-100$ & * & & * & \\
\hline Rudd 1 & Scardinius erythrophthalmus (L) & $<15$ & & * & & \\
\hline Rudd 2 & & $15-30$ & & * & & \\
\hline Rudd 3 & & $30-90$ & & * & & \\
\hline Tench & Tinca tinca $(\mathrm{L})$ & $<200$ & & & & * \\
\hline
\end{tabular}

*Indicates individuals of that species/size class used from that lake for isotope and gut analysis. 
removed quantitatively by depletion with an electrofisher. The area of the isolated patch was then measured. This was repeated at several stations around the lake. Fish density was estimated using the generalised Zippin (1958) maximum-likelihood removal method. To ensure a reasonable coverage of species and size classes of fish, additional individuals were collected by point sampling with the electrofisher around the lake. Fish used for stable isotope analysis were frozen immediately. Other fish were preserved in a solution of $8 \%$ formaldehyde. Fish guts were removed from 10 individuals of each species and size class by dissection (including those used for SIA), and their contents mounted in glycerol and identified using a phase contrast microscope. In size classes where less than 10 individuals were caught all specimens (minimum three) were used. The contribution of each prey species to the diet was determined as the number of individuals of that prey item expressed as a percentage of the total number of prey items in the gut. The amount of detritus, algal and plant material ingested was estimated as the number of fields of view containing such matter divided by the total number of fields examined. Where large amounts of particulate organic matter of allochthonous origin were apparent, additional samples of were collected, particularly at Bluestone Plantation Lake where alder leaves were collected from the lakebed.

Water chemistry variables (Table 1) are annual averages calculated from monthly visits to each site over the period May 1999-May 2000. On each occasion, Secchi depth was measured in situ, and samples of water collected and analysed on return to the laboratory for total phosphorus, soluble reactive phosphorus, nitrate, silicate, chlorophyll $a$, conductivity, alkalinity and $\mathrm{pH}$ using standard methods (Mackereth, Heron \& Talling, 1978).

\section{Isotope analysis}

On return to the laboratory the samples were oven dried $\left(60^{\circ} \mathrm{C}\right.$ for $\left.24 \mathrm{~h}\right)$ on acid washed glass plates. Samples of fish flank muscle tissue were dissected first and dried as above. Snail body tissues were dissected from their shells and the shells discarded prior to drying. All samples were kept separate. Once dried all the samples, except seston and periphyton, were homogenised with a pestle and mortar, or an agate mill if they were particularly coarse, and stored until required in acid-washed glass jars. All equipment was washed in acetone between samples. Where possible, samples corresponded to individuals but, in the case of the smaller invertebrates, several individuals were processed together to provide sufficient mass for isotopic analysis. A cork borer was used to cut disks from the glass fibre filters containing seston and periphyton. Disks from each glass fibre filter, which corresponded to different stations within the lake, were kept separate. An unused glass fibre filter was treated in the same way, to ensure that the influence of the blank was negligible.

Approximately $1 \mathrm{mg}$ of each sample was loaded into a $4 \times 6 \mathrm{~mm}$ tin capsule and combusted in either a Carlo Erba C/N/S analyser (Carlo Erba, Milan, Italy) interfaced with a Finnigan Tracer Matt (Bremen, Germany) continuous flow isotope ratio mass spectrometer (CF-IRMS), or an Europa Scientific ANCA 20/20 CF-IRMS (PDZ Europa Ltd, Northwich, UK). All estimates of isotopic composition were based on at least three measurements and the results are expressed in $\delta$ notation:

$$
\delta I=\left[\frac{R_{\text {sample }}}{R_{\text {standard }}}-1\right] \times 1000
$$

where $I$ is the isotope of interest (either ${ }^{13} \mathrm{C}$ or ${ }^{15} \mathrm{~N}$ ) and $R$ is the ratio of this isotope to the lighter isotope (either ${ }^{12} \mathrm{C}$ or $\left.{ }^{14} \mathrm{~N}\right) . \delta I$ is expressed as the permille $(\%)$ deviation of that sample from the recognised isotope standard (Pee Dee Belemnite for $\delta^{13} \mathrm{C}$ and atmospheric $\mathrm{N}_{2}$ for $\delta^{15} \mathrm{~N}$ ).

A fundamental aim was to determine the relative contribution of different primary producers to the diets of consumers. A mixing model was therefore necessary, although there are limitations of such models, both mathematical and biological (Ben-David \& Schell, 2001; Phillips, 2001; Phillips \& Gregg, 2001). Early approaches based on Euclidean distance did not provide a mathematically correct solution. Overemphasis of contribution to the diet is possible if one source has a signal similar to that of the sink, and exact solutions are not possible unless all end members are included. These problems are compounded by variation in absorption and fractionation between different food sources (Adams \& Sterner, 2000; Ben-David \& Schell, 2001; Phillips \& Koch, 2002) and by variation in the signal of the source dependent upon the relative supply and demand placed upon the element in question (Pennock et al., 1996; Gervais \& Riebesell, 2001). Nevertheless, we follow the advice 
of Ben-David \& Schell (2001) and use these models as a heuristic tool to investigate the patterns within our data, and do not expect them to give exact solutions. We took a pragmatic approach to the problem. First, for both carbon and nitrogen independently, we calculated $\delta$ (predator) that would result from all combinations of putative prey items, in varying proportions. Clearly such an approach is highly dependent on the assumed fractionation between predator and prey, $\Delta_{\text {predator-prey, }}$ which appears to be variable both within and between species (Adams \& Sterner, 2000; Vander-Zanden \& Rasmussen, 2001). Although the quality and quantity of available food may affect $\Delta_{\text {predator-prey, }}$ under natural conditions it is also influenced by omnivory (feeding at more than one trophic level) which causes a reduced $\Delta_{\text {predator-prey }}$ between each predator and the trophic level immediately below. Without accurate description of the diet it is not possible to separate these two effects.

Thus, we calculated the proportion of the putative food sources in the diet using a range of reasonable estimates for $\Delta^{13} \mathrm{C}$ and $\Delta{ }^{15} \mathrm{~N}$. Estimates for $\Delta \Delta^{13} \mathrm{C}$ and $\Delta{ }^{15} \mathrm{~N}$ were selected for each species in $0.1 \%$ increments, where the hypothesised food mix calculated for each isotope coincided to produce the measured $\delta^{13} \mathrm{C}$ and $\delta^{15} \mathrm{~N}$ of the predator. For each species, coincidence was achieved over multiple values of assumed fractionation, producing multiple estimates of dietary proportions. Both the width of the range and the absolute values of assumed fractionation that achieved coincidence varied between species (lowest and highest values used across all species $\Delta^{13} \mathrm{C}$, $0.5-1.3 \%$ per trophic level and $\Delta^{15} \mathrm{~N}, 0.2-3.9 \%$ per trophic level). Finally, the mean proportions of dietary sources were calculated from the range of data generated by varying $\Delta_{\text {predator-prey }}$ through this fractionation range and used in subsequent analysis.

As all collections were made on a single visit to each site we lack information on seasonal variability in the isotopic composition of the primary producers, though results from a eutrophic lake indicate that this may be relatively constant over the summer period (Yoshioka et al., 1994). We also lack rates of turnover of animal tissues, so we do not know the time period reflected by the isotopic composition of the animal. In these lakes the majority of invertebrates are at least univoltine, reproducing in spring, with rapid growth thereafter. Hence, we assume that the isotopic composition of the invertebrates corresponds to a relatively short time period and that the influence of seasonal variation is negligible (as compared to spatial variability between the samples). The work of Yoshioka et al. (1994) supports this position, showing a close coupling between the isotopic composition of invertebrates and fish, and their food sources.

To determine the influence of prevailing conditions on the diet of invertebrates, stepwise multiple regression was conducted on the calculated proportion of periphyton in the diet of the invertebrates. The factors included were fish density, Secchi depth, total phosphorus, soluble reactive phosphorus, nitrate, silicate, chlorophyll a, conductivity, alkalinity and $\mathrm{pH}$ (Table 1).

\section{Results}

\section{Isotopic analysis}

The isotopic composition showed clear separation of the primary producers in all four lakes (Fig. 1). In all cases, seston showed the greatest isotopic discrimination, being substantially ${ }^{13} \mathrm{C}$-depleted relative to the other major algal component of the system, periphyton. The primary producers showed little separation with respect to $\delta^{15} \mathrm{~N}$. Aquatic primary producers in Bluestone Plantation Lake were ${ }^{15} \mathrm{~N}$-enriched $\left(\delta^{15} \mathrm{~N}>11 \%\right.$ o $)$ relative to the other lakes and previously published results (e.g. Yoshioka et al., 1994; Hecky \& Hesslein, 1995; Yoshii, 1999; Grey et al., 2001). This was not true of the leaves of alder (A. glutinosa, $\delta^{15} \mathrm{~N}=3.0 \%$ ), even though the trees were rooted in waterlogged soil and the leaves collected from the lake bed. The high $\delta^{15} \mathrm{~N}$ signal was present in all the other organisms sampled from Bluestone Plantation Lake, indicating that the alder leaves did not contribute significantly to their diet.

With the exception of calanoid copepods from Bluestone Plantation Lake, all other invertebrates fell within the range of isotopic composition of the primary producers, indicating that these carbon sources were the most likely food sources for invertebrates. Although separation of primary producers was possible using $\delta^{13} \mathrm{C}$ and $\delta^{15} \mathrm{~N}$, with few exceptions it was not possible to link consumers unambiguously to their putative food sources. Many of the invertebrates typically classified as grazers of periphyton (Fryer, 1985; Thorpe \& Covich, 1991) had a $\delta^{13} \mathrm{C}$ isotopic composition between that of periphy- 


\section{(a) Bayfield Hall Lake}

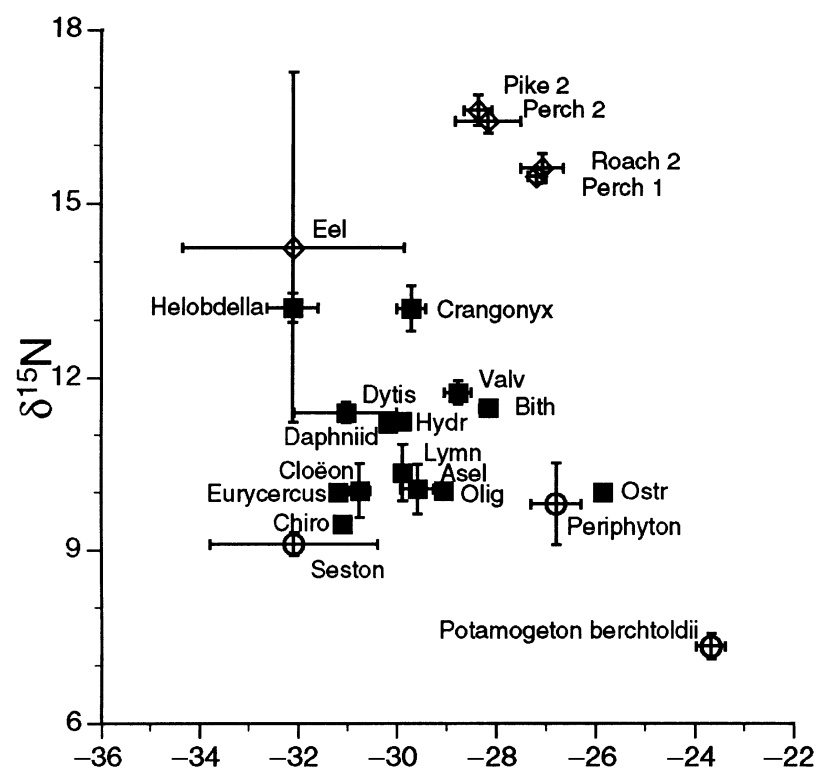

(c) Gunthorpe Hall Lake

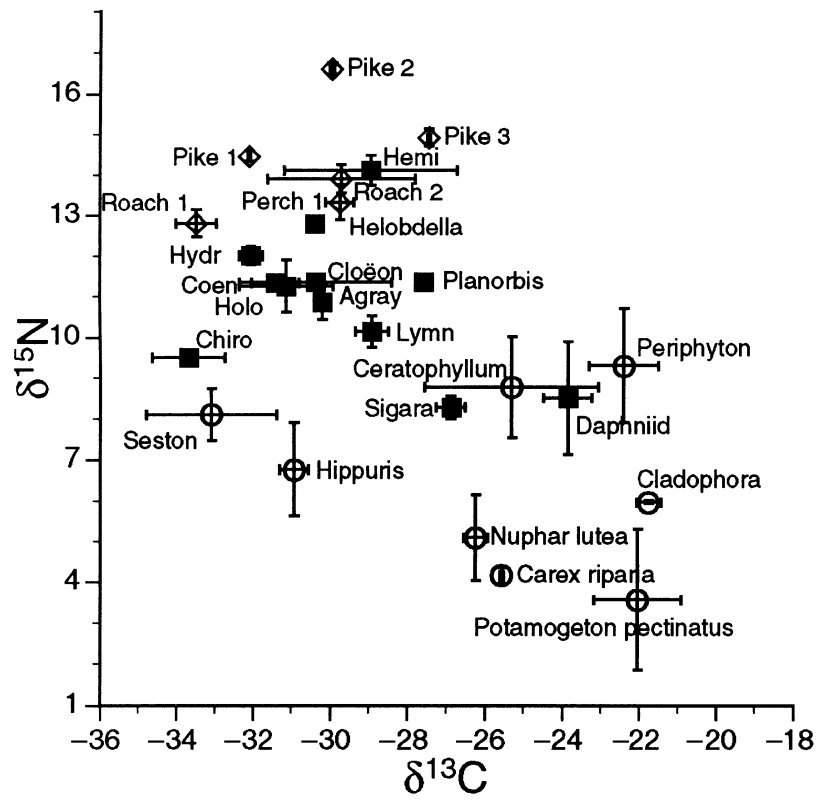

\section{(b) Bluestone Plantation Lake}

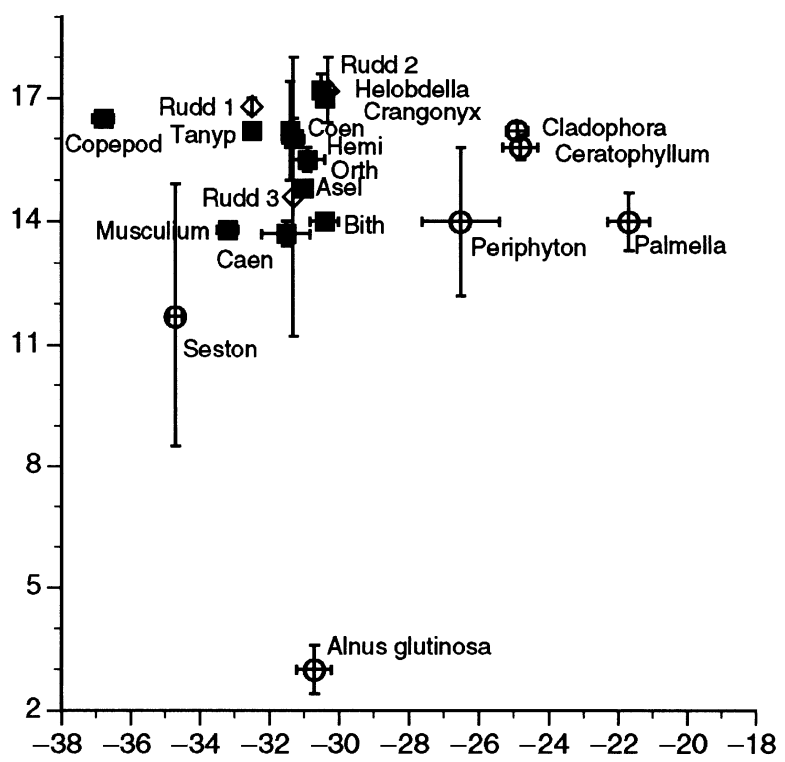

(d) Stradsett Hall Lake

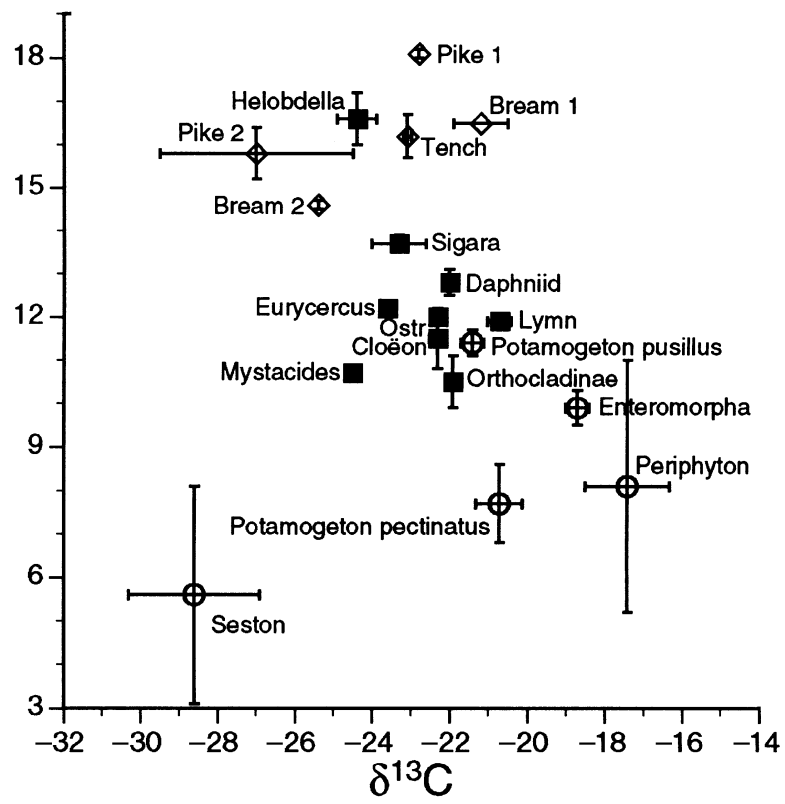

Fig. 1 Results of stable isotope analyses showing mean $( \pm 1 \mathrm{SD})$ of $\delta^{13} \mathrm{C}$ and $\delta^{15} \mathrm{~N}(\%)$ for the primary producers $(\bigcirc)$, invertebrates $(\square)$ and fish $(\diamond)$ in the four study lakes. (a) Bayfield Hall, (b) Bluestone Plantation, (c) Gunthorpe Hall, and (d) Stradsett Hall. Fish species refer to size classes in Table 2. Agray: Agraylea multipunctata; Asel: Asellus aquaticus; Bith: Bithynia tentaculata; Caen: Caenis robusta; Chiro: Chironomini; Coen: Coenagrion puella; Daphniid: Ceriodaphnia reticulata and Daphnia magna; Dytis: Dytiscidae (larvae); Hemi: Hemiclepsis marginata; Holo: Holocentropus dubius; Hydr: Hydracarina; Lymn: Lymnaea peregra; Olig: Oligochaeta; Orth: Orthetrum cancellatum; Ostr: Ostracoda; Tany P: Tanypodinae; Valv: Valvata piscinalis.

ton and seston. A similar situation was noted for daphniid zooplankton, which are generally regarded as feeding predominantly upon seston but had a $\delta^{13} \mathrm{C}$ isotopic composition between periphyton and seston. Separating the invertebrates into trophic levels according to their $\delta^{15} \mathrm{~N}$ was possible in some 
circumstances but not all. This is likely to be a consequence of omnivory (feeding at more than one trophic level) but differences in fractionation of nitrogen from one trophic level may also play a part. For example, in Bayfeld Hall Lake the herbivorous snail Lymnaea peregra (Müll.) was positioned among the primary producers whilst other snails, Valvata piscinalis (Müll.) and Bithynia tenteculata (L.), occupied a more elevated position, similar to that of the predatory larvae of dytiscid beetles (Fig. 1a). Only in Stradsett Hall Lake did $\delta^{15} \mathrm{~N}$ of all the primary consumers differ significantly from their putative food sources (Fig. 1d). Some species described as belonging to the same guild were separated [e.g. the detritivores Crangonyx pseudogracilis Bousfield and Asellus aquaticus (L) from Bayfield Hall Lake], which is likely to be a consequence of inaccurate description of their diet, e.g. C. pseudogracilis being predatory, or possibly by variation in isotopic fractionation between the species.

In all the lakes $\delta^{15} \mathrm{~N}$ values placed fish at the top of the food web, but they appeared to share this position with predatory leeches and C. pseudogracilis. Where present, nominally piscivorous fish [pike, Esox lucius $\mathrm{L}$, and perch, Perca fluviatilis (L)] were most ${ }^{15} \mathrm{~N}$ enriched (Fig. 1a,c,d). Bluestone Plantation Lake does have a few pike, but the sampling strategy employed here failed to catch any.

The $\delta^{13} \mathrm{C}$ of fish differed between species and particularly between size classes. In Bluestone Plantation Lake and Gunthorpe Hall Lake, the cyprinid fish tended to be more ${ }^{13} \mathrm{C}$-depleted with size, whilst in Stradsett Hall Lake the opposite trend occurred. Only one size class of cyprinid fish was caught at Bayfield Hall Lake, where total fish density was the lowest (Table 1). Pike became more ${ }^{13} \mathrm{C}$-enriched with size in Gunthorpe Hall Lake and more ${ }^{13} \mathrm{C}$-depleted with size in Stradsett Hall Lake. In Stradsett Hall Lake and Bluestone Plantation Lake fish tended to decline in $\delta^{15} \mathrm{~N}$ with increasing size suggesting increased reliance upon basal resources, whereas in Bayfield Hall Lake and Gunthorpe Hall Lake they tended to increase, suggesting the opposite. The piscivores followed the other fish but at a higher $\delta^{15} \mathrm{~N}$, reflecting their higher trophic position. Eels [Anguilla anguilla (L)] from Bayfield Hall Lake showed a wide variation in both $\delta^{13} \mathrm{C}$ and $\delta^{15} \mathrm{~N}$, which may reflect varied diet (see below) or, for carbon, be a consequence of heterogeneity in the high lipid content of their tissues (DeNiro \& Epstein, 1977).
Fish guts

A total of 53 different food types were found in the guts of the fish, including 46 invertebrate species. Several of these had not been included in the stable isotope analysis, either because they were too small to be collected by the techniques used (e.g. rotifers), or because there were too few for analysis. The maximum number of different prey types ingested by any fish species/size class was 29 by rudd 3 (see Table 2 for size class) from Bluestone Plantation Lake, and the minimum three by pike 2 in Stradsett Hall Lake. Very few food types were taken by all individual fish of any species/size class. The most noticeable features of the diet of the fish, as discerned by their gut contents, were a high degree of omnivory and a lack of specialism (Fig. 2). All fish species were feeding upon at least two nominal trophic levels and most on three (e.g. plants, herbivorous invertebrates, predatory invertebrates) with items taken from both planktonic and epiphytic/benthic compartments, often all in the same gut. Pike, the only fish found to be feeding piscivorously, were not exclusively so at any stage of life, feeding also upon herbivorous and predatory invertebrates (Fig. 2). Perch 2 in Bayfield Hall had been feeding predominantly upon zooplankton (with some benthic/epiphytic invertebrates) yet appeared to be piscivorous from their $\delta^{15} \mathrm{~N}$ (Fig. 1). Size-based selection of prey was apparent with more frequent large items ingested by older fish; ontogenetic shifts in diet were suggested, but not absolute, for roach and bream. Even the smallest roach and rudd $(<15 \mathrm{~mm}$ body length, Table 2) fed upon both planktonic rotifers and epiphytic invertebrates (Fig. 2), and here the numerical dominance of rotifers in the diet may not reflect the nutritional importance of infrequent larger items taken from the epiphytic/benthic compartment.

\section{Proportion of periphyton in the diet}

The relative contributions of different putative primary producers to the diets of invertebrates were determined using the heuristic mixing model approach outlined in the methods. Only ostracods in Bayfield Hall Lake depended solely upon periphyton production, though some invertebrate species were exclusive to other sources (Fig. 3a). Stepwise multiple regression indicated that only fish 


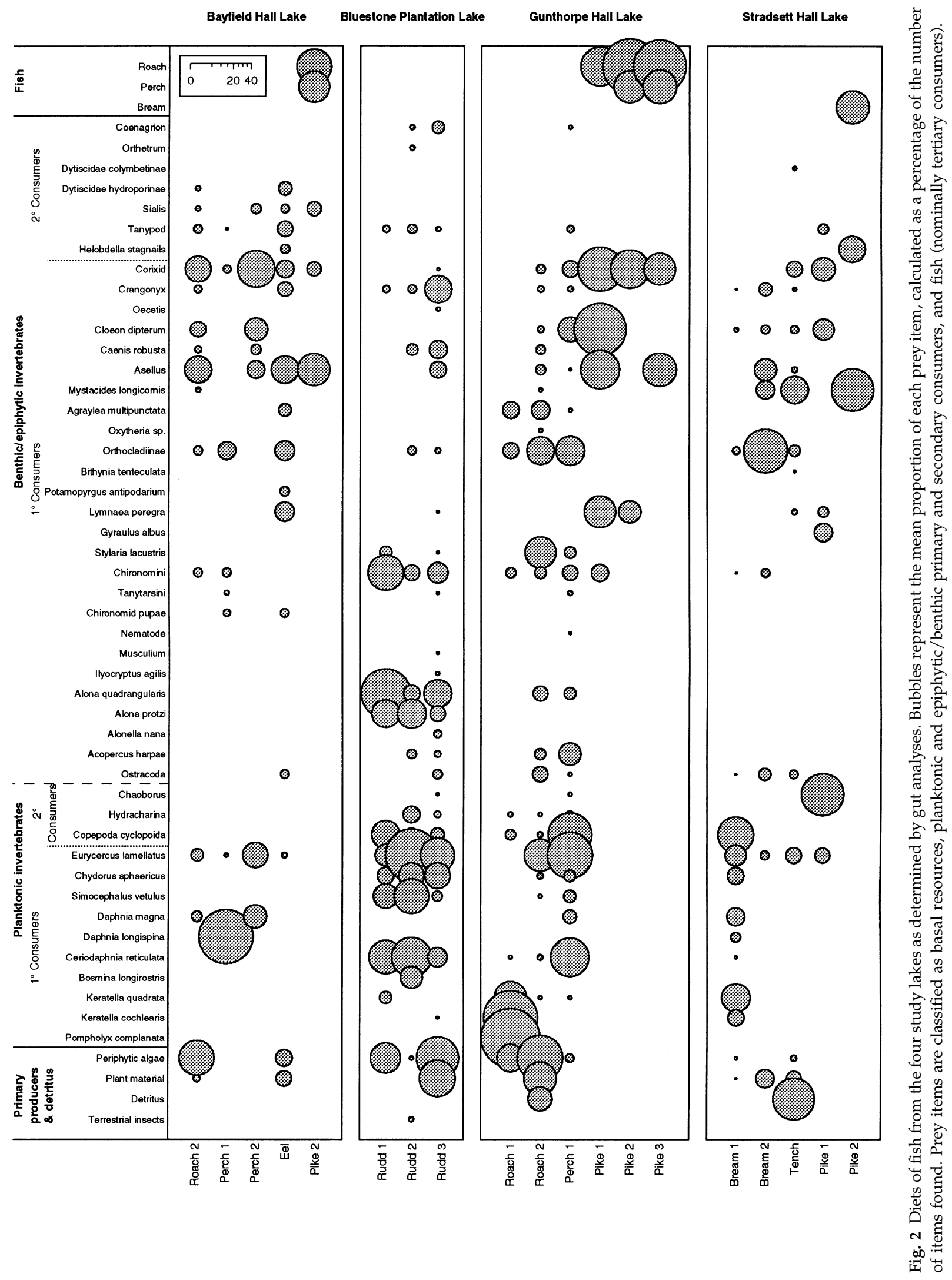


(a)

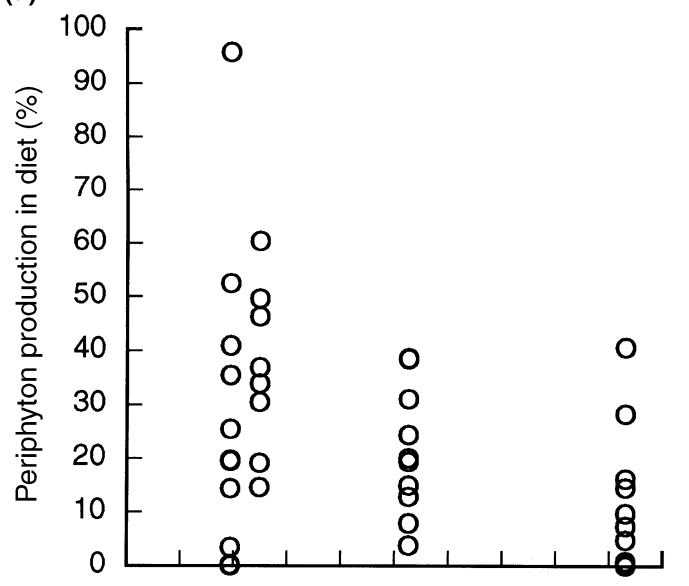

(c)

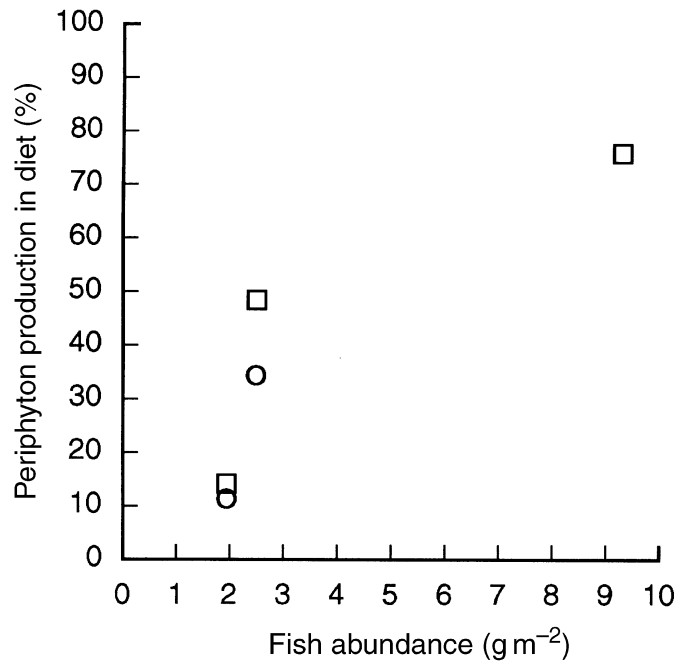

(b)

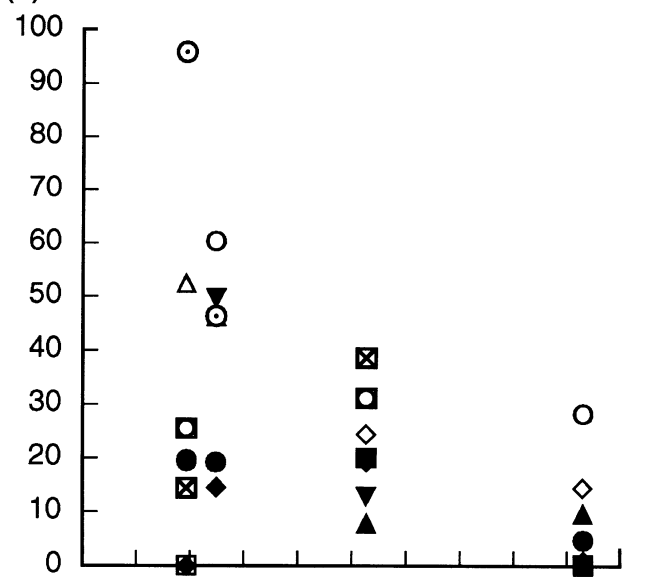

(d)

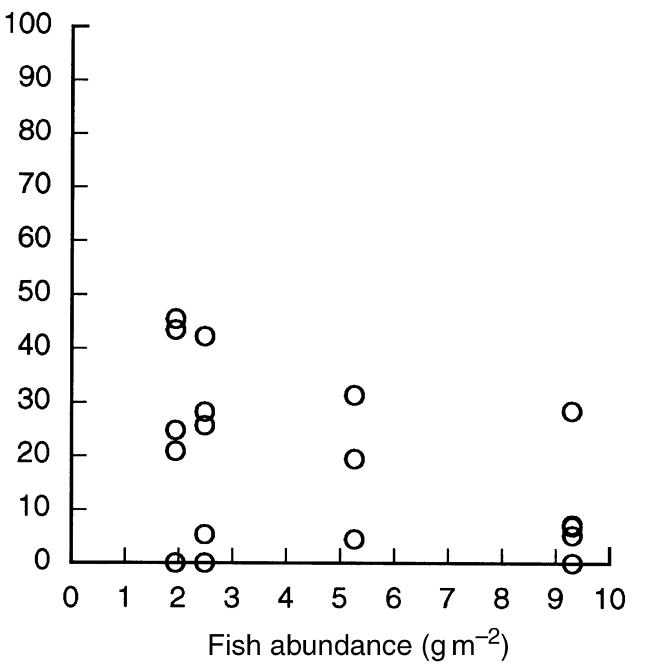

Fig. 3 Relationship between fish density and the percentage of periphyton production supporting the diet as calculated using mixing models (see text for details) of (a) all benthic/epiphytic invertebrates $(P=0.018)$, (b) benthic/epiphytic invertebrate species found in more than one lake $(P=0.022)$, (c) zooplankton species found in more than one lake $(P=0.033)$ and $(\mathrm{d})$ all fish. For $(\mathrm{b})$ and $(\mathrm{c})$, different symbols represent different species in the paired analysis.

density had a significant effect on the proportion of organic matter of periphytic origin in the diet of the invertebrates $(P=0.018$, Fig. 3a). For those species that were found at more than one site, a paired analysis was possible to assess the effect of fish density on the diet of individual species. An ANCOVA of the proportion of periphyton production in the diet of these invertebrates, with species as factors and fish density as the covariate, indicated a declining importance of periphyton with increasing fish density in all species $(P=0.022$ Fig. $3 b)$. Daphniid zooplankton and the chydorid Eurycercus lamellatus (Müll.) were excluded and analysed separately, as they appeared to express an increasing reliance upon periphyton with increasing fish density ( $P=0.033$ Fig. 3c). Using this test there was insufficient power to detect a difference in the response of these two species $(<0.09)$. The contribution of periphyton production to fish tissues varied among species and size classes from 0 to $45 \%$ (Fig. 3d), tending to be lowest in juvenile cyprinids, but was not related to any of the environmental variables tested.

\section{Discussion}

Vegetated shallow lakes are complex, heterogeneous environments with a variety of sources of primary production available for exploitation (Jeppesen et al., 
1998). Nevertheless, it was possible to separate the different sources of primary production in the four study lakes using stable isotope analysis, with separation being most pronounced in $\delta^{13} \mathrm{C}$. This was of particular importance with respect to the separation of attached and planktonic algae, and was most probably a consequence of periphyton having a substantially wider boundary layer and corresponding reduced supply of carbon dioxide than free floating phytoplankton (Hecky \& Hesslein, 1995; Jones, Eaton \& Hardwick, 2000). To an extent it was possible to describe the vertical structure of the food web using $\delta^{15} \mathrm{~N}$. However, it was apparent that the food webs of these lakes were not structured in a simple linear fashion, a consequence of omnivory (feeding at more than one trophic level) which was evident in the fish guts and probable in the invertebrates. Hence, $\delta^{15} \mathrm{~N}$ did not exhibit a typical assumed shift of $3.3 \%$ per 'trophic level' (DeNiro \& Epstein, 1978), although we cannot discount differences in fractionation (Adams \& Sterner, 2000; Ben-David \& Schell, 2001).

In contrast to Hoyer, Gu \& Schelske (1998), both fish and invertebrates displayed a marked lack of dietary specialisation and had been feeding in different compartments (planktonic, epiphytic/ benthic), as well as at different trophic levels. The resultant food web was complex and ascribing species exclusively to putative food sources was impossible. Hence, mixing models were used to determine the extent to which periphyton production supported the diets of higher trophic levels. Numerous invertebrates relied upon organic matter of periphytic origin to an extent, but only ostracods in Bayfield Hall Lake exclusively, and the proportion in the diets of the invertebrates varied in the four lakes. Of all the variables tested, only fish abundance affected the proportion of periphyton production supporting the diet of invertebrates (Fig. 3a). In part, this is due to a change in community composition in response to fish predation, as larger prey items are removed from the community (Diehl \& Kornijów, 1998). To test if invertebrate diet varied in response to fish density, a paired analysis was undertaken using only those species found in more than one lake. The response to increasing fish density was different for planktonic and epiphytic/benthic invertebrates; for zooplankton the proportion of organic matter of periphytic origin in the diet appeared to increase with increased fish density whereas it decreased in other invertebrates (Fig. 3b,c).
Although for benthic/epiphytic invertebrates this may reflect an increased availability of phytoplankton as an indirect effect of fish predation on zooplankton, these changes are consistent (though not conclusive) with the known behavioural responses of invertebrates and zooplankton to predation risk from fish. Zooplankton take refuge in weedbeds by day, migrating into the open water to feed at night (Timms \& Moss, 1984; Burks et al., 2002), whereas plant associated invertebrates leave the plants and take refuge in the benthos during the day (Marklund, Blindow \& Hargeby, 2001). As these responses to predation are likely to be more pronounced with increasing numbers of predators (fish), zooplankton will spend increasingly more time among the plants with potential access to periphyton, whilst other invertebrates will spend less. These results are further evidence for diurnal horizontal migration of zooplankton (Burks et al., 2002), as all samples were collected in the open water at dusk.

The fish had a varied diet, which in part was influenced by their species and size, but in general displayed a lack of specialisation. The presence of littoral vegetation has been shown to influence the diet of fish (Diehl, 1992) inducing a shift to benthic/ epiphytic invertebrate prey (and fish) at an earlier age than their pelagic counterparts (Svanbäck \& Eklöv, 2002). In these shallow lakes the distinction between littoral (vegetated) and pelagic (open water) is less distinct than it is in deep lakes and such clear segregation of habitats is unlikely. With the exception of piscivorous pike, all species fed upon both zooplankton and benthic/epiphytic invertebrates (Fig. 2). Hence, periphyton production supported a substantial proportion of the biomass of higher trophic levels, as found in other lakes (Hecky \& Hesslein, 1995; Yoshii, 1999). None of the variables tested influenced the extent to which fish relied upon periphyton production. As well as a lack of specialisation, omnivory was prevalent in the fish gut contents and suggested from their isotopic composition. All fish species were feeding upon at least two nominal trophic levels and most on three.

To conclude, it is apparent that the food webs of these shallow eutrophic to hypertrophic lakes are complex, characterised by omnivory and generalism. Organic matter is not channelled through separate planktonic and epiphytic/benthic compartments, and the extent to which animals rely upon either is plastic, 
and may be strongly influenced by the perceived risk of predation by fish.

\section{Acknowledgments}

Stable isotope analyses were carried out in the SUERC (Scottish Universities Environmental Research Centre), and were funded by the Natural Environment Research Council, U.K. We are grateful to Dr. Carl Sayer of UCL for data regarding water chemistry, to Angela Beresford and Martin Perrow for assistance in the field, to Rachel Janes for assistance in sample preparation and to Roy and Cavel Docking for accommodation. We are particularly grateful for the kind permission of the landowners to carry out the work on their property, namely Sir Jeremy Bagge, Robin Combe, Jeremy Denholme, and Gavin and William High. J.I. Jones is supported by a NERC Fellowship, GT5/98/21/CB.

\section{References}

Adams T.S. \& Sterner R.W. (2000) The effect of dietary nitrogen content on trophic level ${ }^{15} \mathrm{~N}$ enrichment. Limnology and Oceanography, 45, 601-607.

Ben-David M. \& Schell D.M. (2001) Mixing models in analyses of diet using multiple stable isotopes: a response. Oecologia, 127, 180-184.

Brönmark C. (1994) Effects of tench and perch on interactions in a freshwater, benthic food chain. Ecology, 75, 1818-1828.

Brönmark C. \& Weisner S.E.B. (1992) Indirect effects of fish community structure on submerged vegetation in shallow, eutrophic lakes: an alternative mechanism. Hydrobiologia, 243/244, 293-301.

Burks R.L., Lodge D.M., Jeppesen E. \& Lauridsen T.L. (2002) Diel horizontal migration of zooplankton: costs and benefits of inhabiting the littoral. Freshwater Biology 47, 343-365.

Canfield, D.E.II, Shireman, J.V., Colle, D.E., Haller, W.T., Watkins, C.E.II \& Maceina, M.J. (1984) Predictions of chlorophyll $a$ concentrations in Florida lakes: importance of aquatic macrophytes. Canadian Journal of Fisheries and Aquatic Sciences, 41, 497-501.

Carpenter S.R. \& Kitchell J.F. (1993) The trophic cascade in lakes. Cambridge University Press, Cambridge.

Cattaneo A. \& Kalff J. (1986) The effect of grazer site manipulation on periphyton communities. Oecologia, 69, 612-617.
DeNiro M.J. \& Epstein S. (1977) Mechanism of carbon fractionation associated with lipid synthesis. Science, 197, 261-263.

DeNiro M.J. \& Epstein S. (1978) Influence of diet on the distribution of nitrogen isotopes in animals. Geochemica Cosmochimica Acta, 45, 341-351.

Diehl S. (1992) Fish predation and benthic community structure: the role of omnivory and habitat complexity. Ecology, 73, 1646-1661.

Diehl S. \& Kornijów R. (1998) Influence of submerged macrophytes on trophic interactions among fish and macroinvertebrates. In: The Structuring Role of Submerged Macrophytes in Lakes (Eds E. Jeppesen, M. Søndergaard, M. Søndergaard \& K. Christoffersen), pp. 24-46. Springer-Verlag, New York.

Fry B. (1988) Food web structure on Georges Bank from stable $\mathrm{C}, \mathrm{N}$, and $\mathrm{S}$ isotopic compositions. Limnology and Oceanography, 33, 1182-1190.

Fryer G. (1968) Evolution and adaptive radiation in the Chydoridae Crustacea: Cladocera. A study in the comparative functional morphology and ecology. Philosophical Transactions of the Royal Society of London Series B, 254, 221-385.

Fryer G. (1985) Crustacean diversity in relation to the size of water bodies: some facts and problems. Freshwater Biology, 15, 347-361.

Gervais F. \& Riebesell U. (2001) Effect of phosphorus limitation on elemental composition and stable carbon isotope fractionation in a marine diatom growing under different $\mathrm{CO}_{2}$ concentrations. Limnology and Oceanography, 46, 497-504.

Grey J., Jones R.I. \& Sleep D. (2001) Seasonal changes in the importance of the source of organic matter to the diet of zooplankton in Loch Ness, as indicated by stable isotope analysis. Limnology $\theta$ Oceanography, 46, 505-513.

Hecky R.E. \& Hesslein R.H. (1995) Contributions of benthic algae to lake food webs as revealed by stable isotope analysis. Journal of the North American Benthological Society, 14, 631-653.

Hoyer M.V., Gu B. \& Schelske C.L. (1998) Sources of organic carbon in the food webs of two Florida lakes indicated by stable isotopes. In: The Structuring Role of Submerged Macrophytes in Lakes (Eds E. Jeppesen, M. Søndergaard, M. Søndergaard \& K. Christoffersen), pp. 326-330. Springer-Verlag, New York.

Jeppesen E., Jensen J. P., Kristensen P., Søndergaard M., Mortensen E., Sortkjær O. \& Olrik K. (1990) Fish manipulation as a lake restoration tool in shallow, eutrophic, temperate lakes 2 Threshold, levels 
long-term stability and conclusions. Hydrobiologia, 200/ 201, 219-227.

Jeppesen E., Søndergaard M., Søndergaard M. \& Christoffersen K. (1998) The Structuring Role of Submerged Macrophytes in Lakes. Springer-Verlag, New York.

Jones J.I. \& Sayer, C.D. Does the fish-invertebrateperiphyton cascade precipitate plant loss in shallow lakes? Ecology, in press.

Jones J.I., Moss B. \& Young J.O. (1998) The interactions between periphyton, non-molluscan invertebrates, and fish in standing freshwaters. In: The Structuring Role of Submerged Macrophytes in Lakes (Eds E. Jeppesen, M. Søndergaard, M. Søndergaard \& K.Christoffersen), pp. 69-90. Springer-Verlag, New York.

Jones J.I., Young J.O., Haynes G.M., Moss B., Eaton J.W. \& Hardwick K.J. (1999) Do submerged aquatic plants influence their periphyton to enhance the growth and reproduction of invertebrate mutualists? Oecologia, 120, 463-474.

Jones J.I., Eaton J.W. \& Hardwick K. (2000) The influence of periphyton on boundary layer $\mathrm{pH}$ conditions: a microelectrode investigation. Aquatic Botany, 67, 191206.

Jones J.I., Young J.O., Eaton J.W. \& Moss B. (2002) The influence of nutrient loading, dissolved inorganic carbon and higher trophic levels on the interaction between submerged plants and periphyton. Journal of Ecology, 90, 12-24.

Kairesalo T., Gunnarsson K., Jónasson G.S. \& Jónasson P.M. (1987) The occurrence and photosynthetic activity of epiphytes on the tips of Nitella opaca A.G. Charophyceae). Aquatic Botany, 28, 333-340.

Mackereth F.J.H., Heron J. \& Talling J.F. (1978) Water analysis: some revised methods for limnologists. Freshwater Biological Association, Ambleside.

Marklund O., Blindow I. \& Hargeby A. (2001) Distribution and diurnal migration of macroinvertebrates within dense submerged vegetation. Freshwater Biology, 46, 913-924.

Mazumder A., Taylor W.D., McQueen D.J. \& Lean D.R.S. (1989) Effects of nutrients and grazers on priphyton phosphorus in lake enclosures. Freshwater Biology, 22, 405-415.

Moss B. (1976) The effects of fertilization and fish on community structure and biomass of aquatic
Stable isotope analysis in plant-dominated lakes

macrophytes and epiphytic algal populations: an ecosystem experiment. Journal of Ecology, 64, 313-342.

Pennock J.R., Velinsky D.J., Ludlam J.M., Sharp J.H. \& Fogel M.L. (1996) Isotopic fractionation of ammonium and nitrate during uptake by Skeletonema costatum: implications for $\delta^{15} \mathrm{~N}$ dynamics under bloom conditions. Limnology and Oceanography, 41, 451-459.

Phillips D.L. (2001) Mixing models in analyses of diet using multiple stable isotopes: a critique. Oecologia, 127, 166-170.

Phillips D.L. \& Gregg J.W. (2001) Uncertainty in source partitioning using stable isotopes. Oecologia, 127, 171179.

Phillips D.L. \& Koch P.L. (2002) Incorporating concentration dependence in stable isotope mixing models. Oecologia, 130, 114-125.

Sand-Jensen K. (1977) Effect of epiphytes on eelgrass photosynthesis. Aquatic Botany, 3, 55-63.

Scheffer, M. (1998) Ecology of shallow lakes. Chapman Hall, London.

Svanbäck R. \& Eklöv P. (2002) Effects of habitat and resources on morphology and ontogenetic growth trajectories in perch. Oecologia, 131, 61-70.

Thorpe J.H. \& Covich A.P. (1991) Ecology and classification of North American Freshwater invertbrates. Academic Press, San Diego.

Timms R.M. \& Moss B. (1984) Prevention of growth of potentially dense phytoplankton populations by zooplankton grazing, in the presence of zooplanktivorous fish in a shallow wetland ecosystem. Limnology and Oceanography, 29, 472-486.

Vander-Zanden M.J. \& Rasmussen J.B. (2001) Variation in $\delta^{15} \mathrm{~N}$ and $\delta^{13} \mathrm{C}$ trophic fractionation: implications for aquatic food web studies. Limnology and Oceanography, 46, 2061-2066.

Yoshii K. (1999) Stable isotope analysis of benthic organisms in Lake Baikal. Hydrobiologia, 411, 145-159.

Yoshioka T., Wada E. \& Hayashi H. (1994) A stable isotope study on seasonal food web dynamics in a eutrophic lake. Ecology, 75, 835-846.

Zippin C. (1958) The removal method of population estimation. Journal of Wildlife Management, 22, 82-90.

(Manuscript accepted 8 May 2003) 